\title{
Bioedusiana
}

http://jurnal.unsil.ac.id/index.php/bioed/index

DOI: https://doi.org/10.34289/292825

\section{PENGARUH PEMBELAJARAN GUIDED INQUIRY TERHADAP KEMAMPUAN BERPIKIR KRITIS DAN RETENSI PESERTA DIDIK PADA KONSEP SISTEM INDERA MANUSIA Studi Eksperimen di Kelas XI MIA MAN 1 Tasikmalaya Tahun Ajaran 2017/2018 (The Impact of Guided Inquiry Learning Models on Student's Critical Thinking Skills and Retention in Concept of Human Sensory Systems)}

\author{
Vina Amalia Wahyuni ${ }^{1)}$, Endang Surahman ${ }^{1)}$, Romy Faisal Musthofa ${ }^{1)}$ \\ ${ }^{1)} J u r u s a n$ Pendidikan Biologi, Fakultas Keguruan dan Ilmu Pendidikan Universitas Siliwangi \\ J1. Siliwangi No. 24 Post Code 164 Tlp. (0265) 330634 Tasikmalaya 46115 \\ Email korespondensi: vinaamalia13@gmail.com
}

\begin{abstract}
Info Artikel
Abstrak

Sejarah Artikel:

Diterima:

05 Mei 2019

Disetujui:

14 Oktober 2019

Dipublikasikan:

01 Desember 2019

Keywords:

Guided Inquiry,

Kemampuan Berpikir Kritis, Retensi, Sistem Indera

Manusia

Penelitian ini bertujuan untuk mengetahui pengaruh pembelajaran guided inquiry terhadap kemampuan berpikir kritis dan retensi peserta didik pada konsep sistem indera manusia di kelas XI MIA MAN 1 Tasikmalaya. Penelitian ini dilaksanakan pada bulan Oktober 2017 sampai dengan bulan Juni 2018 di MAN 1 Tasikmalaya. Metode yang digunakan dalam penelitian ini adalah true experiment. Populasi dalam penelitian ini adalah seluruh kelas XI MIA MAN 1 Tasikmalaya. Sampel penelitian sebanyak 2 kelas yaitu, kelas XI MIA 4 dengan proses pembelajaran menggunakan model pembelajaran guided inquiry dan kelas XI MIA 5 dengan proses pembelajaran menggunakan model pembelajaran direct instruction, yang diambil dengan teknik cluster sampling. Instrumen yang digunakan dalam penelitian ini adalah tes kemampuan berpikir kritis dan retensi peserta didik pada konsep sistem indera. Tes kemampuan berpikir kritis diukur dengan menggunakan soal uraian sebanyak 12 nomor, dan retensi diukur dengan menggunakan soal uraian singkat sebanyak 24 nomor. Teknik analisis data yang digunakan adalah ANCOVA. Berdasarkan hasil penelitian diperoleh simpulan, ada pengaruh pembelajaran guided inquiry terhadap kemampuan berpikir kritis dan retensi peserta didik serta ada hubungan kemampuan berpikir kritis dengan retensi peserta didik pada konsep sistem indera manusia di kelas XI MIA MAN 1 Tasikmalaya.
\end{abstract}

\begin{abstract}
This research aims to determine the effect of guided inquiry learning to ability of critical thinking and retention of learners on the concept of the human sense system in the class XI MIA MAN 1 Tasikmalaya. This research was conducted in October 2017 until June 2018 at MAN 1 Tasikmalaya. The method that used in this research was true experiment. The population in this research was all class XI MIA MAN 1 Tasikmalaya. The sample of research was 2 classes that is class XI MIA 4 with learning process using guided inquiry and XI MIA 5 learning model with learning process using direct instruction learning model, taken by cluster random sampling technique. The instruments used in this study are the critical thinking skills and retention of learners on the concept of sense systems. The critical thinking skills test is measured using a description of 12 numbers, and retention is measured using a brief description of 24 numbers. The data analysis technique used is ANCOVA. Based on the research results obtained conclusion, there is the influence of guided inquiry learning on the ability of critical thinking and retention of learners, also there is a correlation between critical thinking ability and retention the student's in human sense system concept in class XI MIA MAN 1 Tasikmalaya.
\end{abstract}

(C) 2019 Universitas Siliwangi

Alamat korespondensi:

Jurusan Pendidikan Biologi FKIP Universitas Siliwangi

Gedung Perkantoran FKIP Lt. 3

Jalan Siliwangi No. 24 Kota Tasikmalaya 46115

HP. 08112344989 (a.n. Rinaldi Rizal Putra, M.Sc.)

E-mail: bioedusiana@unsil.ac.id
ISSN: 2684-7604 (online)

ISSN: 2477-5193 (print) 


\section{PENDAHULUAN}

Pembelajaran

bermakna akan meninggalkan pemahaman yang baik bagi peserta didik. Corebima (Ardila, et.al., 2013) menyatakan bahwa "Hasil dari suatu pembelajaran bermakna berpeluang besar bermakna, baik yang terkait dengan aspek kognitif, afektif maupun psikomotor". Pemahaman proses pembelajaran ini berkaitan dengan aspek kognitif. Pemahaman terhadap aspek kognitif tentunya akan lebih bermakna jika tidak mudah segera hilang diingatan. Dalam hal ini, retensi memegang peranan yang penting. Surya (Antika, et.al., 2013) menyatakan bahwa "Retensi merupakan kemampuan seseorang untuk mengingat seberapa banyak hal yang telah dialami atau dipelajari".

Ketika seseorang memiliki kemampuan mengingat yang baik, maka akan mendukung proses kognitif untuk mengembangkan kemampuan berpikir kritis. Banikowski (Fauziyah, et.al., 2013) menyatakan bahwa "Ingatan atau memori memiliki peran penting dalam proses pembelajaran tidak hanya dalam dimensi menghafal saja, tetapi lebih kepada dimensi berpikir kritis, belajar, menghubungkan, mengingat, dan menggunakan seluruh pengetahuan serta kemampuan yang pernah didapat". Sehingga peserta didik yang mempunyai kemampuan retensi baik akan mampu memproses informasi dengan baik untuk dapat mengembangkan kemampuan berpikir kritis dalam proses pembelajaran.

Berdasarkan hasil observasi yang telah dilakukan di melalui wawancara dengan guru biologi dan melihat proses pembelajaran, ketika guru mengaitkan dengan materi pembelajaran pertemuan sebelumnya peserta didik menunjukan tidak mampu mengingat informasi yang telah diterima dalam proses belajar. Masalah lain adalah proses pembelajaran dan soal-soal evaluasi belum terarah pada kemampuan berpikir kritis peserta didik sehingga sedikit peserta didik yang terbiasa untuk mengembangkan kemampuan berpikir kritis.

Diperlukan suatu upaya perbaikan dalam proses pembelajaran di kelas terutama dalam penggunaan model pembelajaran yang tepat yang sesuai dengan kondisi peserta didik untuk mampu mengembangkan kemampuan berpikir kritis dan retensi dalam pembelajaran. Model guided inquiry merupakan salah satu model pembelajaran yang dapat dijadikan solusi untuk proses pembelajaran peserta didik. Model ini melibatkan peserta didik secara maksimal dalam mencari dan menemukan berbagai sumber informasi dan ide-ide yang mengarahkan untuk melakukan penyelidikan dalam upaya membangun pengetahuan dan makna baru. Proses pembelajaran seperti ini akan melibatkan secara maksimal seluruh kemampuan peserta didik sehingga proses penyelidikan yang dilakukan akan memberikan pemahaman yang lebih baik dan menjadi lebih bermakna.

Masalah penelitian ini dirumuskan sebagai berikut: "adakah pengaruh model pembelajaran guided inquiry terhadap kemampuan berpikir kritis dan retensi peserta didik pada konsep sistem indera di kelas XI MIA MAN 1 Tasikmalaya?".

Tujuan dari penelitian ini adalah untuk mengetahui pengaruh model pembelajaran guided inquiry terhadap kemampuan berpikir kritis dan retensi serta mengetahui hubungan kemampuan berpikir kritis dengan retensi peserta didik pada konsep sistem indera manusia di kelas XI MIA MAN 1 Tasikmalaya.

\section{METODE}

Metode penelitian yang digunakan dalam penelitian ini metode true experiment, karena pada desain eksperimen ini terdapat dua kelas yang akan dijadikan sebagai subjek penelitian, dengan model pembelajaran guided inquiry sebagai variabel bebas dan kemampuan berpikir kritis serta retensi peserta didik sebagai variabel terikat.

1. Populasi dan Sampel

Populasi dalam penelitian ini adalah seluruh kelas X MIA MAN 1 Tasikmalaya tahun ajaran 2017/2018 sebanyak 7 kelas dengan sampel yang digunakan adalah 2 kelas, yang diambil dengan menggunakan teknik cluster sampling, yaitu kelas X MIA 4 menggunakan model pembelajaran guided inquiry dan kelas X MIA 5 menggunakan model pembelajaran direct instruction.

2. Desain Penelitian

Desain penelitian yang digunakan dalam penelitian ini adalah posttest control group design. Desain penelitian yang digunakan menurut Creswell (2013:243) adalah: 


\begin{tabular}{|lll|}
\hline $\mathrm{R}$ & $\mathrm{X}$ & $\mathrm{O}_{1}$ \\
$\mathrm{R}$ & & $\mathrm{O}_{2}$ \\
\hline
\end{tabular}

3. Teknik Pengumpulan Data

Teknik pengumpulan data yang digunakan dalam penelitian ini adalah teknik tes. Tes yang digunakan pada penelitian ini adalah tes kemampuan berpikir kritis yang berbentuk uraian dan tes retensi yang berbentuk uraian singkat untuk membandingkan kemampuan berpikir kritis dan retensi peserta didik akibat perlakuan yang berbeda.

4. Teknik Pengolahan dan Analisis Data

Teknik pengolahan dan analisis data dalam penelitian ini yaitu dengan uji persyaratan analisis menggunakan $\mathrm{Uji}$ Normalitas dengan Uji kolmogorof-smirnov dan Uji homogenitas dengan levene's test, kemudian dilanjutkan dengan uji hipotesis menggunakan uji ANCOVA.

5. Instrumen Penelitian

Instrumen yang digunakan dalam penelitian ini adalah tes kemampuan berpikir kritis dan retensi peserta didik pada sub konsep sistem indera. Instrumen kemampuan berpikir kritis yang digunakan dalam bentuk uraian dan aspek yang diukur mengacu pada lima indikator berpikir kritis. Sementara instrumen retensi dalam bentuk isian singkat.

\section{HASIL DAN PEMBAHASAN}

1. Data Hasil Penelitian

Data yang diperoleh dari penelitian ini meliputi data posttest dari kemampunan berpikir kritis (Tabel 1) dan retensi (Tabel 2) peserta didik pada materi sistem indera di kelas XI MIA MAN 1 Tasikmalaya.

Tabel 1. Statistik Hasil Tes Kemampuan Berpikir Kritis Peserta Didik Kelas Eksperimen dan Kelas Kontrol

\begin{tabular}{|l|r|r|}
\hline \multirow{2}{*}{} & \multicolumn{2}{|c|}{ Postest Kemampuan Berpikir Kritis } \\
\cline { 2 - 3 } & Kelas Eksperimen & \multicolumn{1}{|c|}{ Kelas Kontrol } \\
\hline Rata-rata & 28 & 18 \\
\hline Standar Deviasi & 2,732 & 3,397 \\
\hline Varians & 7,465 & 11,540 \\
\hline Minimum & 22 & 13 \\
\hline Maksimum & 33 & 28 \\
\hline Jumlah & 856 & 432 \\
\hline
\end{tabular}

Tabel 2. Statistik Hasil Retensi Peserta Didik Kelas Eksperimen dan Kelas Kontrol

\begin{tabular}{|l|r|r|}
\hline \multirow{2}{*}{} & \multicolumn{2}{|c|}{ Postest Kemampuan Berpikir Kritis } \\
\cline { 2 - 3 } & Kelas Eksperimen & \multicolumn{1}{c|}{ Kelas Kontrol } \\
\hline Rata-rata & 41,61 & 39,19 \\
\hline Standar Deviasi & 2,186 & 1,797 \\
\hline Varians & 4,778 & 3,228 \\
\hline Minimum & 38 & 35 \\
\hline Maksimum & 45 & 42 \\
\hline Jumlah & 1290 & 1215 \\
\hline
\end{tabular}

2. Pengujian Hipotesis

Ringkasan pengujian hipotesis disajikan pada Tabel 3 berikut. Hasil pengujian hipotesis menyimpulkan bahwa "ada pengaruh model guided inquiry terhadap kemampuan berpikir kritis dan retensi peserta didik pada konsep sistem indera di kelas XI MIA MAN 1 Tasikmalaya" dapat diterima. 
Tabel 3. Ringkasan Hasil Uji ANCOVA

\begin{tabular}{|l|r|r|r|r|l|}
\hline \multicolumn{1}{|c|}{ Source } & $\begin{array}{c}\text { Type III Sum } \\
\text { of Squares }\end{array}$ & \multicolumn{1}{c|}{ Df } & $\begin{array}{c}\text { Mean } \\
\text { Square }\end{array}$ & \multicolumn{1}{c|}{ F } & \multicolumn{1}{c|}{ Sig. } \\
\hline Corrected Model & 316,294 & 2 & 158,147 & 44,59 & 0,000 \\
\hline Intercept & 962,070 & 1 & 962,070 & 271,2 & 0,000 \\
\hline Kemampuan Berpikir Kritis & 17,972 & 1 & 17,972 & 5,067 & 0,028 \\
\hline Model & 18,203 & 1 & 18,203 & 5,132 & 0,027 \\
\hline Error & 209,254 & 59 & 3,547 & & \\
\hline Total & 96394,000 & 62 & & & \\
\hline Corrected Total & 525,548 & 61 & & & \\
\hline a. R Squared =0,602 (Adjusted R Squared =0,588) \\
\hline
\end{tabular}

3. Pembahasan

Berdasarkan hasil penelitian yang dilakukan dan setelah diuji dengan menggunakan uji ANCOVA untuk mengetahui pengaruh kemampuan berpikir kritis sebagai kovariat dan perbedaan model terhadap retensi peserta didik secara simultan dapat dilihat dari angka signifikasi pada bagian corrected model. Nilai signifikasi hasil pengujian adalah 0,000 . Karena nilai signifikasi jauh dibawah 0,05 maka Ho ditolak. Sehingga pada tingkat kepercayaan $95 \%$ atau 0,05 dapat disimpulkan bahwa secara simultan model guided inquiry berpengaruh terhadap kemampuan berpikir kritis dan retensi peserta didik.

Adanya pengaruh tersebut disebabkan karena karakteristik model guided inquiry dapat melatih kemampuan berpikir kritis. Melalui pembelajaran guided inquiry peserta didik dilibatkan secara maksimal dalam mencari dan mengolah informasi untuk menemukan jawaban dari suatu permasalahan. Peserta didik akan termotivasi untuk mengembangkan kemampuan berpikir dalam menghadapi dan mencari solusi dari suatu masalah. Selain itu memungkinkan mengasah peserta didik untuk berpikir kritis tentang pelajaran yang kurang dipahami dengan cara berdiskusi dengan peserta didik lainnya. Hal tersebut selaras dengan pernyataan Sularso et.al (2015) yang mengemukakan bahwa "Model inkuiri terbimbing mampu mengakomodasi rasa ingin tahu peserta didik yang akan mendorong peserta didik untuk mulai mencari tahu konsep yang ada dalam pembelajaran atau kegiatan yang mereka alami, sehingga merangsang kemampuan berpikirnya".

Model ini dapat digunakan untuk melatih kemampuan berpikir kritis terutama dalam pemecahan masalah, karena peserta didik harus menganalisis berbagai informasi untuk menemukan solusi yang tepat. Seperti yang dikemukakan oleh Sutama et.al (2014) bahwa "pembelajaran inkuiri selain berorientasi kepada hasil belajar juga berorientasi pada proses belajar. Tujuannya adalah untuk mengembangkan kemampuan berpikir".

Selain itu model guided inquiry merupakan model yang melibatkan peserta didik secara maksimal dalam mencari dan mengolah informasi sehingga menghasilkan pembelajaran yang bermakna. Peserta didik yang mengalami pembelajaran secara bermakna akan lebih mengingat materi pelajaran di dalam kelas sehingga memiliki retensi yang baik. Silmiati (2017) mengungkapkan bahwa "Pembelajaran yang bermakna bagi siswa dapat lebih mempertahankan retensi yang dimiliki oleh siswa". Bruner (Sutama, Nyoman et.al., 2014)) menyatakan bahwa "Keuntungan mengajar dengan model inkuiri adalah salah satunya membantu siswa dalam menggunakan daya ingat dan transfer pada situasi-situasi proses belajar yang baru". Demikian halnya Santi et.al (2014) menyatakan bahwa "Pembelajaran inkuiri dapat menimbulkan pembelajaran yang bermakna untuk mendapatkan pengetahuan. Pengetahuan ini akan memberikan 
kemampuan untuk mengingat sesuatu lebih lama dan memberikan pemahaman yang mendalam". Hal ini karena tahapan pada model guided inquiry membantu peserta didik dalam memahami informasi berupa konsep melalui serangkaian kegiatan seperti mengumpulkan dan menganalisis data, sehingga materi yang telah dipelajari tertanam dalam memori jangka panjang.

Pernyataan tersebut dapat didukung secara deskriptif melalui perolehan skor ratarata posttest. Peserta didik pada kelas eksperimen yang proses pembelajarannya menggunakan model guided inquiry memperoleh skor rata-rata posttest kemampuan berpikir kritis sebesar 28,23 dan skor rata-rata posttest retensi sebesar 41,61. Sementara peserta didik pada kelas kontrol yang proses pembelajarannya menggunakan model direct instruction memperoleh skor rata-rata posttest kemampuan berpikir kritis sebesar 18,45 dan skor rata-rata posttest retensi sebesar 39,19.

Gambar 1 menunjukkan skor rata-rata kemampuan berpikir kritis dan retensi pada kelas eksperimen yang menggunakan model guided inquiry lebih tinggi dibandingan dengan kelas kontrol yang menggunakan model direct instruction. Hal ini menunjukkan bahwa model guided inquiry dapat meningkatkan kemampuan berpikir kritis dan retensi peserta didik.

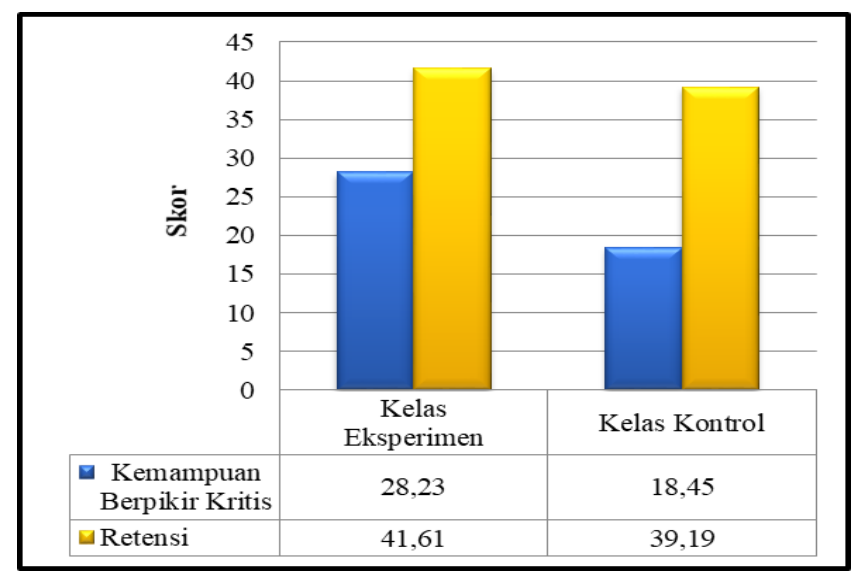

Gambar 1. Diagram Skor Rata-rata Posttest Kemampuan Berpikir Kritis dan Retensi Peserta Didik di Kelas Eksperimen dan Kelas Kontrol

Didukung oleh Sutama et.al (2014) yang menyatakan bahwa "Manfaat yang diperoleh bagi siswa dalam pembelajaran inkuiri adalah siswa akan memahami konsep-konsep dasar dan ide-ide lebih baik, membantu dalam menggunakan daya ingat dan transfer pada situasi-situasi proses belajar yang baru dan mampu mengembangkan kemampuan berpikir kritis siswa".

Demikian halnya Santi et.al (2014) mengemukakan bahwa "Pada tahap perumusan masalah peserta didik akan mengoptimalkan pengetahuan awal yang dimiliki. Pengetahuan ini termasuk belajar bermakna karena pengetahuan yang didapatkan akan memberikan kemampuan untuk mengingat sesuatu lebih lama dan memberikan pemahaman yang lebih mendalam". Sehingga dapat disimpulkan bahwa pembelajaran guided inquiry berpengaruh secara signifikan terhadap kemampuan berpikir kritis dan retensi peserta didik pada sub konsep sistem indera di kelas XI MIA MAN 1 Tasikmalaya.

Kemudian berdasarkan hasil penelitian dan pengujian menggunakan uji ANCOVA untuk mengetahui pengaruh model guided inquiry terhadap kemampuan berpikir kritis yang diperoleh peserta didik dapat dilihat dari angka signifikasi pada bagian model yang terdapat pada tabel 3. Dari hasil pengolahan diperoleh nilai signifikasi sebesar 0,027 . Karena berada di bawah 0,05 maka Ho di tolak, sehingga didapatkan kesimpulan 
bahwa model guided inquiry berpengaruh terhadap kemampuan berpikir kritis peserta didik.

Selain itu pengaruh model guided inquiry terhadap retensi peserta didik, berdasarkan hasil pengujian diperoleh nilai signifikasi pada tabel 2 sebesar 0,027. Karena berada di bawah 0,05 maka Ho di tolak, sehingga didapatkan kesimpulan bahwa model guided inquiry berpengaruh terhadap retensi peserta didik. Pengaruh tersebut disebabkan karena terdapat kesesuaian antara model guided inquiry dengan pemprosesan informasi.

Hasil penelitian dan pengujian untuk melihat hubungan antara kemampuan berpikir kritis sebagai kovariat dengan retensi menggunakan uji ANCOVA didapatkan nilai signifikasi hubungan linier kemampuan berpikir kritis dengan retensi peserta didik sebesar 0,028 karena nilainya di bawah 0,05 maka Ho di tolak. Sehingga dapat disimpulkan ada hubungan linier antara kemampuan berpikir kritis peserta didik sebagai kovariat dengan retensi.

Peserta didik yang mempunyai kemampuan retensi yang baik akan mampu memproses informasi dengan baik sehingga dapat mengambangkan kemampuan berpikirnya untuk dapat menganilisis suatu permasalahan. Hal ini di dukung oleh Banikowski (Fauziyah et.al., 2013) yang menyatakan bahwa "Retensi atau ingatan atau memori memiliki peran penting dalam proses pembelajaran tidak hanya dalam dimensi menghafal saja, tetapi lebih kepada dimensi berpikir kritis dan menggunakan seluruh pengetahuan serta kemampuan yang pernah didapat".

\section{SIMPULAN, SARAN, DAN REKOMENDASI}

1. Simpulan

Berdasarkan hasil penelitian, pengolahan data, dan pengujian hipotesis maka diperoleh simpulan bahwa model guided inquiry berpengaruh terhadap kemampuan berpikir kritis dan retensi peserta didik pada konsep sistem indera di kelas XI MIA MAN 1 Tasikmalaya tahun pelajaran 2017/2018.

2. Saran dan Rekomendasi

Saran dan rekomendasi untuk penelitian berikutnya antara lain:

a. dalam penerapan model pembelajaran guided inquiry guru hendaknya mempersiapkan kebutuhan guna meminimalisasi kendala yang mungkin terjadi dan menjelaskan secara rinci tentang model pembelajaran yang akan diterapkan kepada peserta didik;

b. guru hendaknya menggunakan model pembelajaran guided inquiry khususnya pada materi-materi biologi yang bersifat autentik dan realistik untuk meningkatkan kemampuan berpikir kritis dan retensi;

c. bagi peneliti selanjutnya, hendaknya mencoba menerapkan model pembelajaran guided inquiry pada materi yang lain dan atau pada peningkatan kemampuan berpikir tingkat tinggi yang lain; dan

d. bagi peneliti selanjutnya, hendaknya mencoba menerapkan model pembelajaran pembelajaran lain seperti problem based learning untuk meningkatkan kemampuan berpikir kritis dan retensi peserta didik.

\section{UCAPAN TERIMA KASIH}

Penulis menyampaikan ucapan terima kasih yang sebesar-besarnya kepada Bapak Dr. H. Endang Surahman, M.Pd., beserta Bapak Romy Faisal Musthofa, M.Pd., selaku kolaborator dalam penelitian ini. Kemudian kepada Ibu Neneng Lilies, S.Pd., selaku guru mata pelajaran Biologi Kelas XI MIA

\section{DAFTAR PUSTAKA}

Antika, L.T., et al. (2013). "Perbandingan Keterampilan Metakognitif, Hasil Belajar Biologi, dan Retensi Antara Siswa Berkemampuan Akademik Tinggi dan Rendah Kelas X SMA Di Malang Melalui Strategi Problem based learning (PBL)". SKRIPSI Jurusan BiologiFakultas MIPA UM. Malang. 
Ardila, C. et al. (2013). "Hubungan Keterampilan Metakognitif Terhadap Hasil Belajar Biologi Dan Retensi Siswa Kelas X Dengan Penerapan Strategi Pemberdayaan Berpikir Melalui Pertanyaan (PBMP) di SMAN 9 Malang". Online Journal of the State University of Malang, Indonesia . Malang.

Creswell, J. W. (2015). Research Design Pendekatan Kualitatif, Kuantitatif, dan Mixed Method. Yogyakarta: Pustaka Belajar.

Fauziyah, D. R., et al. (2013). "Hubungan Keterampilan Metakognitif terhadap Hasil Belajar Biologi dan Retensi Siswa Kelas X dengan Penerapan Strategi Pembelajaran Think Pair Share di SMA Negeri 6 Malang". Biology Education. Malang.

Kartika, S. et.al. (2014). Pengaruh Model Pembelajaran Inkuiri Terhadap Kemampuan Berpikir Kritis dan Sikap Ilmiah Mahasiswa pada Mata Kuliah Ilmu Alamiah Dasar. Jurnal Pendidikan IPA Indonesia (2).

Sarwono, J. (2012). IBM SPSS Advanced Statistic. Yogyakarta: C. V Andi Offset

Silmiati, N. Y. (2017). "Perbandingan retensi siswa SMP pada pembelajaran IPA terpadu konsep cahaya antara model pembelajaran berbasis masalah dan metode pembelajaran inkuiri”. Jurnal Penelitian Pendidikan, 17(1). Tasikmalaya

Sularso, A., Karyanto, P., \& Sugiharto, B. (2015). "Pengaruh Penggunaan Model Pembelajaran Inkuiri Ditinjau Dari Gaya Belajar Siswa Kelas X SMA N Karangpandan Tahun Pelajaran 2012 / 2013. Bio-Pedagogi , 4 (2). 1-4. Surakarta.

Sutama, I. Nyoman, et al. (2014). "Pengaruh Model Pembelajaran Inkuiri Terhadap Ketrampilan Berpikir Kritis dan Keterampilan Proses Sains pada Pelajaran Biologi Kelas XI IPA SMA Negeri 2 Amlapura". Jurnal Pendidikan IPA, $\quad 4(1) . \quad$ Singaraja. 
Vina Amalia Wahyuni dkk. / Bioedusiana 4 (2) (2019) 